Nemanja Berber, Milan Pasula, Milan Radošević

\title{
2.1 PERFORMANCE MANAGEMENT IN FUNCTION OF DETERMINING INCENTIVE SYSTEMS FOR MANAGERS
}

\begin{abstract}
Summary: Performance management, a very important process of human resource management (HRM), can be significant basis for creating the incentive systems for managers. Big enterprises usually reward their chief executive officer (CEO) for success in business. In the past period the amounts of managers' rewards was not correlated with achieved performances of enterprises, so it was important to analyze amount of rewards given to the managers and methods that can be used to measure achieved managerial performances. Subject of this paper was the analysis of compensation systems for managers in ten most successful companies of the world and their relation with the business results presented trough specific indicators of performances. In addition, the paper was subjected to the analysis of several methods of measuring performances that can be used in determining realistic amounts and structures of CEO rewards and incentives. The aim of this study was the presentation of the relation between managers' rewards and business performances and to find more objective methods for determining these rewards. Thus, compensation packages can meet the requirements of effectiveness and efficiency in terms of long-term goals and performances of business system.
\end{abstract}

Keywords: human resource management, compensations, incentives, performance management, methods for performance measurement

\section{INTRODUCTION}

Performance management is a very important process of human resource management (HRM). It implies an assessment of current or previous results or performance of the employee, team or the whole organization. On such assessments companies creates its policies in many business areas related to HRM: the need for staff training, new recruitment, rewarding, etc. In the area of rewards, performance measurement can be significant basis for creating the incentive systems for managers. Namely, big enterprises usually reward their CEO for success in business. Companies were often very generous in the reward practice for managers. But, in the past period, the amounts of managers' rewards was not correlated with achieved performances of enterprises, so it was important to analyze amount of rewards given to the managers and methods that can be used to measure achieved managerial performances.

Subject of this paper was the analysis of compensation systems for managers in ten most successful companies of the world and their relation with the business results presented trough specific indicators of performances. Paper was subjected to the analysis of several methods of measuring performances that can be used in determining realistic amounts and structures of CEO rewards and incentives. The aim of this study was the presentation of the relation between managers' rewards and business performances and more objective methods for determining these rewards so that compensation packages can meet the requirements of effectiveness and efficiency in terms of long-term goals and performances of business system.

The paper is consisted from tree parts. In the first part authors defined performance measurement and performance measurement system. Second part was related to the analysis of the performances in the 10 most successful companies from USA (according to the list of the magazine Fortune 500) and to the analysis of the compensations of the CEOs in those companies. Third part was dedicated to the presentation of the more comprehensive 
measurement systems of performances that will be better solution for the determining and creation of the CEO compensations. There are explained BSC and EVA concept.

\section{PERFORMANCE MANAGEMENT}

Performance measurement is an assessment of current or previous results of performance of the employee. Performance evaluation approach can be two fold - individual level and on exact data. First approach involves contact by type "face to face"; it is difficult for assessors because it activates emotions that can easily lead to conflict. Another approach focuses on the process of working that is based on exact data - results of the quantification and comparison with the standards (Štangl Šušnjar and Zimanji, 2005). PM in HRM can be made by different management methods such as management by objectives, multilaterally evaluation, bars, the method of critical events, ranking, essays, etc. Based on these established results, managers acquire the possibility of additional compensation by developing a system of benefits.

At the beginning of the analysis we have presented some often cited definition of performance measurement (PM) and performance measurement systems (PMS). According to Neely, Gregory and Plats (1995) performance measurement is defined as "the process of quantifying effectiveness and efficiency of actions'. One comprehensive definition of performance measurement is that PM is "the process of quantifying the efficiency and effectiveness of actions, in order to compare results against expectations, with the intent to motivate, guide and improve decision making" (Lardenoije, Van Raaij and Van Weele, 2005). Lebas (1995) characterizes performance management system as "the philosophy supported by performance measurement. It is the organization-wide shared vision, teamwork, training, incentives, etc. that surround the performance measurement activity". PM system is "the set of metrics used to quantify the efficiency and effectiveness of actions, and the corresponding guidelines for linking these metrics to strategy and improvement" (Lardenoije, Van Raaij and Van Weele, 2005). The performance measures should be relevant, balanced, based on financial and non-financial indicators and related to internal and external stakeholders. Measures need to be related directly to the organization's mission and objectives in order to reflect the company's external competitive environment, customer requirements and internal objectives (Kennerley and Neely, 2002).

It is important to notice some contemporary researches made in relation to the importance of PM in modern business. Nudurupati, Bititci, Kumar and Chan (2011) have reviewed and tackled the evolution of the performance measurement field in the context of information systems and change management. According to Bititci, Garengo, Dörfler and Nudurupati (2011) concluded that in general the performance measurement field seemed to have developed in response to global and business trends. Also, many other researches have been made to explain PM and its implementation in each area of business: profit, non-profit, public, private, etc. In this paper, PM was analyzed as the base for managerial compensations.

\section{PERFORMANCE MANAGEMENT AS THE BASE FOR CREATING MANAGERIAL INCETIVE COMPENSATIONS}

When it comes to the compensation for managers, performance management gets even bigger role. The current bureaucratic models of determining these systems had the impact on their low motivational force as well as on problems between the owners and managers in terms of high agency costs. The most analyzed problem was the correlation of compensations with the performances of managers. So far, many studies revealed that there is no strong correlation between these variables. For example, in the research of author Ozkan (2011, p. 260), it have been pointed out to a weak effectiveness of corporate governance 
reports in the UK, which suggested that compensation for managers should be more closely linked with their performance. In one other research it was found that annual change in managerial compensation in the US during the $70 \mathrm{~s}$ and $80 \mathrm{~s}$ of the twentieth century to a large extent were not correlated with changes in corporate performances - the total compensation of managers have varied only $\$ 3$ to every $\$ 1,000$ change in shareholder wealth (Jensen and Murphy, 2010, p. 64). Since managerial compensations are very complex category of HRM, there have to be made changes in modelling incentive compensations. Adequate systems of compensation for managers should be structured on the basis of actual performance. Also, it would be necessary to determine the controllable and non controllable factors (in the sense of those factors that are in the power of manager).

If the long and short-term incentives for managers are in the question, a very interesting attitude was expressed by Malinić (2007) where he stated that:

- Short-term compensation should be based on standard financial indicators, such as profit (with variations to make it after tax, profit before tax and profit before interest and taxes), rate of return, cash flow, earnings per share and the like; and longterm compensation should be tied to several criteria that respect the long-term profitability; long-term position of the company and movement of the total shareholder returns (dividends and capital gains).

- Criteria for achieving long-term compensation imposed are the market value of companies, economic value added-EVA, market value added-MVA, the total shareholder return - TSR and others.

For the more comprehensive view of the performance measures and indicators in Table 1 there are summarized the indicators for the evaluation of the performance of the organization.

Table 1: Performance management tools and indicators

\begin{tabular}{|l|r|}
\hline \multicolumn{2}{|c|}{ PERFORMANCE MANAGEMENT TOOLS } \\
\hline \multicolumn{1}{|c|}{ FINANCIAL INDICATORS } & $\begin{array}{c}\text { INDICATORS OF TOTAL } \\
\text { PERFORMANCES }\end{array}$ \\
\hline Return on Investment (ROI) & Balanced scorecard (BSC) \\
\hline Return on Assets (ROA) & Tableau du Board (TdB) \\
\hline Return on Equity (ROE) & Performance Prism (PPR) \\
\hline Earnings per Share (EPS) & Performance Pyramid System (PPS) \\
\hline Cash flow (CF) & Productivity Measurement and Enhancement \\
Revenue (I) & System (ProMES) \\
\hline Profit (P) & \\
\hline Total Shareholder return (TSR) & Market Value Added (MVA) \\
\hline Economic Value Added (EVA) &
\end{tabular}

Source: Malinić, 2007; Lardenoije, Van Raaij, Van Weele, 2005.

In order to show the level of compensation, their structure and relation to the performance, it has been made the analysis of performances of the top ten USA companies (according to Fortune 500) and its managerial reward packages. Table 2 and 3 presented the performance indicators (table 2) and the level and structure of CEO compensations (table 3) for 2010. All data in table 2 are gained from Fortune list 500 (http://money.cnn.com). For table 3 it has been used the research of Hay Group for 2010 (http://www.haygroup.com).

According to data in tables, it can be concluded next:

- Each company from table 2, except Bank of America and Fannie Mae, had a profitable business 2010 year. There has been noticed the growth of revenues and profits, accompanied with the growth of earning per share (EPS) from 2009 to 2010 . For example, the growth of the revenue is between 3.3 and $32.6 \%$ (Fannie Mae reached even $429.2 \%$ 
higher revenue than in 2009), the growth of profit is between 5.6 and $141.5 \%$. EPS growth was from 20.8 to $135.2 \%$.

- Each company, except Bank of America and Fannie Mae, had positive indicators of ROA, ROE and ROI, which means that those companies have created return on assets, investments and equity. This can be explained as short-term gain for the company since all those indicators are related to the annual business and financial operations.

- Companies reward their CEO with different elements of compensations, but it can be concluded that main are: base salary; annual incentives; long term incentives - stock options grants, restricted stock grants, performance-based grants in equity and cash; all other compensations (perquisites, personal benefits, tax gross-ups, discount stock purchases); change in nonqualified deferred compensation earnings plus change in pension value.

- Basic salary is the smallest part of the total compensations, and it estimates from $6.97 \%$ (in Wall Mart) to $16.8 \%$ (in General Electric) of total compensations. In companies that did not create long and short-term incentives, salary is the biggest or even the only element of the compensations (Berkshire Hathaway and General Motors). Basic salary is determined by the working contract between managers and companies, and it is fixed amount that is paid with no relation to the performances.

- Annual incentives are usually double or even several times bigger than salary. These incentives are paid in almost each company where have been created positive business result, profit and performance indicators of ROA, ROE, ROI and EPS. In Bank of America annual incentives were not paid since that corporation realized loss in 2010 of \$2,238 millions. Annual incentives are usually paid for the short time period.

- Long-term incentives have reached level from $58 \%$ to $74 \%$ of total compensations, with the exception of General Electric Company (LTI are only $22 \%$ of total compensations). Long-term incentives are differently used in each company. The most used are stock options, restricted stocks and performance based equity grants. The performance based cash grants were used only by one company. In addition, five companies form the Table 3 used two LTI elements in rewarding its CEO - stock options and performance based equity grants. Last five companies decided to give to the CEOs only one LTI incentive restricted stock grant.

- Related to the long term incentives is also the tendency of rewarding CEO with more deferred compensations. Namely, performance based cash grants were used only in General Electric Company. All other companies gave to the CEOs compensations in form of capital - equity and stocks. For example, restricted stocks were given as compensation in four out of ten companies. Stock options were used in four cases.

- Since the economic crisis had affected the business and economy in many world countries, wastefully CEO compensation models became untenable. HR managers are trying to create models that will be enough motivating but also sustainable in means of real business performances. The goal of any compensation system should be to attract, motivate and retain the best managers, while at the same time being fair to the shareholders. 
Table 2: The performances of the 10 most successful companies from the list of Fortune in 2010

\begin{tabular}{|c|c|c|c|c|c|c|c|c|c|c|c|c|c|c|c|c|}
\hline \multirow[b]{2}{*}{$\mathbf{R}$} & \multirow[b]{2}{*}{ Company } & \multicolumn{7}{|c|}{ Key financial elements in millions of \$ } & \multirow[b]{2}{*}{$\begin{array}{l}\operatorname{Pr} \\
(\%)\end{array}$} & \multirow[b]{2}{*}{$\begin{array}{c}\text { ROA } \\
(\%)\end{array}$} & \multirow[b]{2}{*}{$\begin{array}{l}\text { ROE } \\
(\%)\end{array}$} & \multicolumn{3}{|c|}{ EPS } & \multicolumn{2}{|c|}{ ROI } \\
\hline & & Revenues & $\begin{array}{c}\% \\
\text { change } \\
\text { from } \\
2009\end{array}$ & Profits & $\begin{array}{c}\% \\
\text { change } \\
\text { from } \\
2009\end{array}$ & Assets & $\begin{array}{c}\text { Stockholders' } \\
\text { equity }\end{array}$ & $\begin{array}{c}\text { Market } \\
\text { value } \\
(\mathbf{3} / \mathbf{2 5} / \mathbf{2 0 1 1})\end{array}$ & & & & $\begin{array}{c}2000- \\
2010 \\
\text { Annual } \\
\text { growth } \\
(\%) \\
\end{array}$ & $\begin{array}{c}2010 \\
\$\end{array}$ & $\begin{array}{r}\% \\
\text { change } \\
\text { from } \\
2009\end{array}$ & $\begin{array}{c}2000- \\
2010 \\
\text { Annual } \\
\text { rate } \\
(\%) \\
\end{array}$ & $\begin{array}{l}2010 \\
(\%)\end{array}$ \\
\hline 1 & Wal-Mart Stores & 421,849 & 3.3 & 16,389 & 14.3 & 180,663 & 68,542 & 182,764 & 3.9 & 9.1 & 23.9 & 12.3 & 4.47 & 20.8 & 1.4 & 3.2 \\
\hline 2 & Exxon Mobil & 354,674 & 24.6 & 30,460 & 58 & 302,510 & 146,839 & 414,638 & 8.6 & 10.1 & 20.7 & 9.5 & 6.22 & 56.3 & 7.7 & 10.1 \\
\hline 3 & Chevron & 196,337 & 20.1 & 19,024 & 81.5 & 184,769 & 105,081 & $214,355.5$ & 9.7 & 10.3 & 18.1 & 9.1 & 9.48 & 80.9 & 11.6 & 22.9 \\
\hline 4 & ConocoPhillips & 184,966 & 32.6 & 11,358 & 133.8 & 156,314 & 68,562 & $116,812.3$ & 6.1 & 7.3 & 16.6 & 7.7 & 7.62 & 135.2 & 12.2 & 38.8 \\
\hline 5 & Fannie Mae & 153,825 & 429.2 & $-14,014$ & N.A. & $3,221,972$ & $-2,599$ & 447.9 & -9.1 & -0.4 & N.A. & N.A. & -3.81 & N.A. & -42.1 & -74.6 \\
\hline 6 & General Electric & 151,628 & -3.3 & 11,644 & 5.6 & 751.216 & 118.936 & $209,715.2$ & 7.7 & 1.6 & 9.8 & -1.8 & 1.06 & 5.0 & -6.3 & 23.9 \\
\hline 7 & Berkshire Hathaway & 136,185 & 21.1 & 12,967 & 61 & 372,229 & 157,318 & $210,787.5$ & 9.5 & 3.5 & 8.2 & 13.8 & 7.0 & 52.7 & 5.4 & 21.4 \\
\hline 8 & General Motors & 135,592 & 29.6 & 6,172 & N.A. & 138,898 & 36,180 & $49,116.6$ & 4.6 & 4.4 & 17.1 & N.A. & 2.89 & N.A. & N.A. & N.A. \\
\hline 9 & Bank of America & 134,194 & -10.8 & $-2,238$ & -135.7 & $2,264,909$ & 228,248 & $135,016.2$ & -1.7 & -0.1 & -1.0 & N.A. & -0.37 & N.A. & -1.7 & -11.2 \\
\hline 10 & Ford Motor & 128,954 & 9 & 6,561 & 141.5 & 164,687 & -673 & 55,715 & 5.1 & 4.0 & N.A & -3.2 & 1.66 & 93.0 & -1.2 & 67.9 \\
\hline
\end{tabular}

Source: http://money.cnn.com (systematized data according to the list of Fortune 500)

Table 3: CEO compensations of the 10 most successful companies from the list of Fortune in 2010

\begin{tabular}{|c|c|c|c|c|c|c|c|c|c|c|c|c|c|}
\hline \multirow{3}{*}{$\mathbf{R}$} & \multirow{3}{*}{ Company } & \multicolumn{12}{|c|}{ Elements of total compensations for CEO in (000 \$) } \\
\hline & & \multirow[b]{2}{*}{ Salary } & \multirow{2}{*}{$\begin{array}{l}\text { An. } \\
\text { incenti } \\
\text { ves }\end{array}$} & \multicolumn{4}{|c|}{ Long term incentives (000\$) - LTI } & \multirow{2}{*}{$\begin{array}{c}\text { Total } \\
\text { direct } \\
\text { compensati } \\
\text { ons }\end{array}$} & \multirow{2}{*}{$\begin{array}{c}\text { Change in } \\
\text { Nonqualified Deferred } \\
\text { Compensation }+ \\
\text { Change in Pension } \\
\text { Value }\end{array}$} & \multirow{2}{*}{$\begin{array}{c}\text { All Other } \\
\text { Compensat } \\
\text { ion }\end{array}$} & \multirow[b]{2}{*}{$\begin{array}{c}\text { Total } \\
\text { Compensation }\end{array}$} & \multirow{2}{*}{$\begin{array}{l}\text { Total } \\
\text { Realized } \\
\text { LTI }\end{array}$} & \multirow{2}{*}{$\begin{array}{l}\text { 3-Year Realized } \\
\text { Total Direct } \\
\text { Compensation }\end{array}$} \\
\hline & & & & $\begin{array}{l}\text { Stock } \\
\text { option } \\
\text { grants }\end{array}$ & $\begin{array}{c}\text { Restricted } \\
\text { stock } \\
\text { grants }\end{array}$ & $\begin{array}{c}\text { Performance } \\
\text { Based Grant } \\
\text { Equity }\end{array}$ & $\begin{array}{l}\text { Performance } \\
\text { Based Grant } \\
\text { Cash }\end{array}$ & & & & & & \\
\hline 1 & Wal-Mart Stores & $1,232.7$ & $3,852.1$ & 0 & $3,347.5$ & $9,304.9$ & 0 & $17,737.1$ & 499.1 & 476.6 & $18,712.7$ & $17,592.8$ & N.A. ${ }^{6}$ \\
\hline 2 & Exxon Mobil & $2,207.0$ & $3,360.0$ & 0 & $15,465.4$ & 0 & 0 & $21,032.4$ & $7,476.3$ & 443.9 & $28,952.6$ & $7,989.7$ & $33,000.2$ \\
\hline 3 & Chevron & $1,479.2$ & $3,000.0$ & $5,535.2$ & 0 & $3,752.4$ & 0 & $13,776.8$ & $2,273.3$ & 220.5 & $16,260.5$ & $3,101.7$ & N.A. \\
\hline 4 & ConocoPhillips & $1,500.0$ & $4,252.5$ & $5,737.7$ & 0 & $6,148.6$ & 0 & $17,638.8$ & 0 & 294.1 & $17,932.9$ & $9,566.3$ & $36,299.1$ \\
\hline 5 & Fannie Mae & N.A. & N.A. & N.A. & N.A. & N.A. & N.A. & N.A. & N.A. & N.A. & N.A. & N.A. & N.A. \\
\hline 6 & General Electric & $3,300.0$ & $4,000.0$ & $7,400.0$ & 0 & 0 & $4,950.0$ & $19,650.0$ & $6,339.0$ & 389.8 & $26,378.8$ & $1,933.1$ & $25,093.6$ \\
\hline 7 & Berkshire Hathaway & 100.0 & 0 & 0 & 0 & 0 & 0 & 100.0 & 0 & 429.9 & 524.9 & 0 & 300.0 \\
\hline 8 & General Motors & 2.333 .3 & 0 & 0 & 666.7 & 0 & 0 & $3,000.0$ & 0 & 194.1 & $3,194.1$ & 0 & N.A. \\
\hline 9 & Bank of America & 950.0 & 0 & 0 & $9,050.0$ & 0 & 0 & $10,000.0$ & 719.8 & 270.2 & $10,990.1$ & $1,039.3$ & N.A. \\
\hline 10 & Ford Motor & $1,400.0$ & $9,450.0$ & $7,500.0$ & 0 & $7,492.5$ & 0 & $25,842.5$ & 0 & 678.0 & $26,520.5$ & $9,298.0$ & $25,888.0$ \\
\hline
\end{tabular}

Source: http://www.haygroup.com (systematized data according to the list of CEO compensations survey 2010)

${ }^{6}$ Data not available 
After the Tables 2 and 3 are discussed, it can be concluded that there are many issues related to the amount and structure of CEO compensation. These remunerations should be based on outcomes and total business performances of the company. Since only financial indicators are not suitable for the total compensation system, it should me mentioned some other performance measurement model in practice that could be linked to this problem. From all models presented in Table 1, BSC and EVA were found as the performance measurement models that can be used in function of efficient and effective CEO compensation systems.

\section{PERFORMANCE MEASUREMENT SYSTEMS FOR CEO INCENTIVE COMPENSATIONS IN PRACTICE}

\subsection{THE BALANCED SCORECARD (BSC)}

One of the best-known performance measurement system is the balanced scorecard (BSC), developed by Kaplan and Norton (1992; 1996; 1996a). Kaplan and Norton (1996a) define the BSC as "a multidimensional framework for describing, implementing and managing strategy at all levels of an enterprise by linking, through a logical structure, objectives, initiatives, and measures to an organization's strategy".

Figure 1: Balanced Scorecard (BSC)

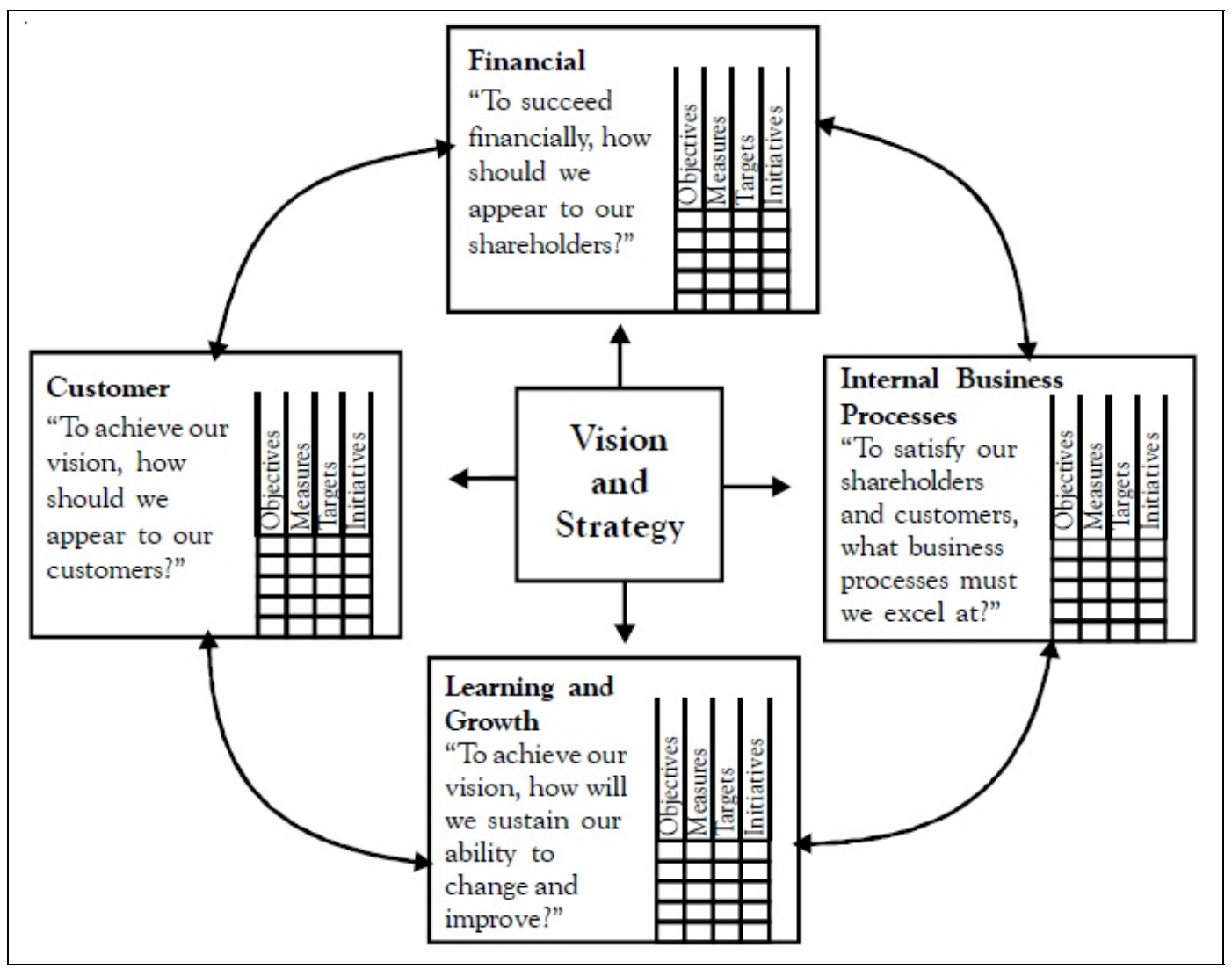

Source: Kaplan and Norton, 1996, p. 76

BSC complements the traditional financial performance measures with three non-financial key performance indicators (KPIs) which are presented in Figure 1:

- financial perspective that is typically related to profitability;

- customer perspective that includes several generic measures of successful outcomes from the company - customer satisfaction, market share; 
- internal processes that focuses on the internal processes that will have the greatest impact on customer satisfaction and on achieving the organization's financial perspectives;

- learning and growth - the infrastructure of the organization has to build and manage to create long-term growth and improvement through people, systems and organizational procedures, is identified in this perspective (Lardenoije, Van Raaij and Van Weele, 2005).

Since Silk (1998) estimated that $60 \%$ of Fortune 1000 companies in the USA have had experienced BSC, there is a need of analyzing this performance measurement model in function of CEO compensations. Pollanen and Xi (2011) had investigated the use of BSC measures in executive compensation plans, particularly its performance consequences, and the fit between the use of BSC and firm characteristics. The findings underscored the importance of firm characteristics in the design and use of performance measurement and reward systems. Also, Creamer and Freund (2010) analyzed the BSC and one of the most important parts of its dataset was CEO compensations. They demonstrated how the boosting approach can be used to define a data driven board BSC with applications to 500 biggest USA companies.

According to Purcell $(2011$, p. 7) "board is at the apex of a company's internal incentive structure and it is the board's decisions that shape the incentives culture for the whole organization and determine whether or not virtue - or its opposite - will be rewarded". Boards must give enough weight to the intangible aspects of executive compensation, and not simply evaluate executive compensation in purely financial terms. Purcell emphasized that boards need to "incorporate the intangible drivers of responsible behaviour into a balanced scorecard gate opener for executive rewards to be triggered".

Table 4: Executive compensation systems according BSC dimensions

\begin{tabular}{|l|l|c|}
\hline \multicolumn{1}{|c|}{ Category } & \multicolumn{1}{|c|}{ Measure } & Weighting \\
\hline \multirow{3}{*}{ Financial (60\%) } & EVA & $25 \%$ \\
& Unit Profit & $20 \%$ \\
& Market Growth & $15 \%$ \\
\hline \multirow{2}{*}{ Customer (20\%) } & Customer satisfaction survey & $10 \%$ \\
& Dealer satisfaction survey & $10 \%$ \\
\hline \multirow{2}{*}{ Internal Process (10\%) } & Above average rank on industry quality survey & $5 \%$ \\
\hline \multirow{2}{*}{ Innovation and Learning (10\%) } & Decrease in dealer delivery cycle time & $5 \%$ \\
& Suggestions/employee & $5 \%$ \\
& Emp. satisfaction survey & $5 \%$ \\
\hline
\end{tabular}

Source: Jones (2009)

Without further literature analysis, in Table 4 it has been presented the example of CEO incentive compensation designed according to BSC. Jones (2009) claimed that CEO paid bonus percentage should be tied to the percentage of exceeding performance targets. From Table 4 it can be seen that main part of the CEO bonus should be related to its financial performances, measured by EVA, unit profit and market growth $(60 \%$ of total earned bonus is consisted from financial indicators). The rest of $40 \%$ is related to customer's indicators $(20 \%)$, indicators of internal processes $(10 \%)$ and indicators of learning and innovation $(10 \%)$. 


\subsection{ECONOMIC VALUE ADDED (EVA)}

About the importance of EVA in function of increasing shareholder value there have been done many studies (Zakić, Vunjak, Bešić, Simić, 2012; Ilić, 2010; Ilić, 2009; Malinić, 2007; Balsley, 2005; Evans and Evans, 2002; Young and O'Byrne, 2001; Stern, Shiely, Ross, 2001; Wallace, 1997). EVA is defined as the change in the NOPAT (Net Operating Profit after Taxes) minus the change in the Cost of the Capital used to generate this NOPAT (Kumar and Kaura, 2002; Sharma and Kumar, 2010). EVA depends basically on the firm operating profit, taxes, debt level, and the cost of capital. EVA directs attention of the company or its managers on the value creation for shareholders. It suggests that managers focus on the question whether a company creates a yield above the cost of capital and thus help managers to analyze the reasons for the changes that are introduced. Therefore, in recent years the economic value added is often used as a basis for the establishment of a compensation system to motivate managers, so they behave in a manner that ensures the creation of shareholder value (Anđelković and Pešić, 2005, p. 54).

EVA can provide investors with a normal return on the company's shares - that is important not only for securities analysts in evaluating stocks, but also for corporate compensation committees in setting performance standards for management incentive compensation plans (O'Byrne, 1996). An examination of the compensation structure and economic value added of 209 companies in 1995 - 1998 provided evidence supporting incentive compensation where EVA is found to be positively and significantly related to incentive based compensation (Evans and Evans, 2002). Also, Dinu and Ciora (2012) in their research have presented the implementation of EVA as value based management technique for incentive compensation. Namely, EVA bonus plan measures excess EVA improvement as opposed to simply EVA growth over prior periods. It provides a more direct link to the true measure of shareholder wealth creation - returns above market expectations (Young and O'Byrne, 2001). Following formula can be used to calculate CEO bonus in each year:

$$
\text { Current Year Bonus }=\text { Target Bonus }+y \%(\Delta E V A-E i)
$$

Target bonus is "the bonus earned by a manager for delivering the EVA improvement that is expected by investors. This expected EVA improvement should be equivalent to the EVA that will provide shareholders with a cost of capital return on the market value of their investment in the business" (Balsley, 2005). If EVA is below this level bonuses will be reduced while returns of shareholders do not fall to zero. At this level there will be no bonuses for managers. $\triangle \mathrm{EVA}$ - EI represents "the change in EVA less expected EVA improvement. This is meant to capture the incremental EVA that a manager has delivered above and beyond the EVA growth that investors expect and have already paid for. The percentage of the incremental performance that is returned to management (y) is established by the compensation committee" (Balsley, 2005).

Additional incentives beyond the level of the target bonus are provided for increasing the EVA above the level provided by covering the total cost of capital and only the part of EVA that is increased above the expected level. In this way it will be prevented the excessive increase of compensation costs. If the criteria for bonuses was any increase in EVA, then there will be situations in which one reached EVA (above the level that provides target bonus) is decreasing, which is usually accompanied by a decline in value of shares and managers will still exercise bonuses over target level (Malinić, 2007). Because of this, Stern Stewart \& Co proposed the use of a "bonus bank" designed to base a manager's annual bonus payout on multi-period EVA delivery (presented in Figure 2). 
Figure 2: EVA bonus bank

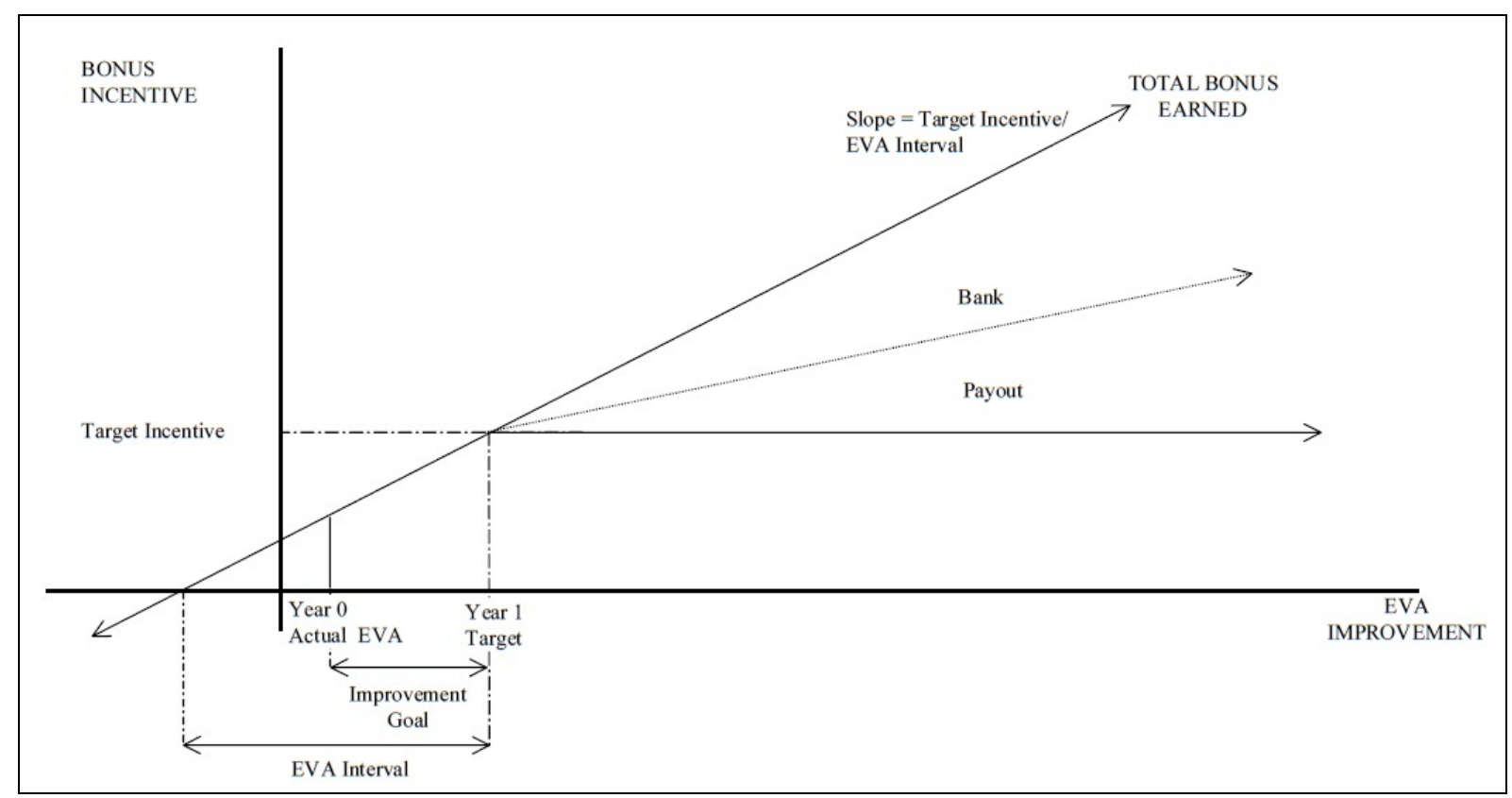

Source: Desai, Ferri, Treadwell, 2006, p. 20

According to bonus bank concept:

- In every year, the "current year bonus" is calculated using the formula described above and based on the manager's performance during that year.

- That "current year bonus" is then placed in a "bonus bank" that also holds the deferred (or unpaid portion of) bonuses from prior years.

- The bonus bank balance (after the current year bonus has been included), rather than the current year bonus, then determines the amount of bonus actually earned by a manager each year. The amount earned is determined in two steps:

- first, $100 \%$ of the bonus bank (if possible) is paid up to the amount of the target bonus;

- $\quad$ second, plus $1 / 3$ of the remaining bonus bank (after the target bonus) (Balsley, 2005).

Table 5: Hypothetical example of the EVA bonus

\begin{tabular}{|l|r|r|r|}
\hline & Business Unit 1 & \multicolumn{1}{c|}{ Business Unit 2 } & \multicolumn{1}{c|}{ Business Unit 3 } \\
\hline \hline Beginning of period EVA (\$) & $20,000,000$ & $40,000,000$ & $10,000,000$ \\
\hline End of period EVA (\$) & $30,000,000$ & $50,000,000$ & $12,000,000$ \\
\hline Incremental EVA Delivered (\$) & $\mathbf{1 0 , 0 0 0 , 0 0 0}$ & $\mathbf{1 0 , 0 0 0 , 0 0 0}$ & $\mathbf{2 , 0 0 0 , 0 0 0}$ \\
\hline Expected EVA Improvement (\$) & $\mathbf{5 , 0 0 0 , 0 0 0}$ & $\mathbf{1 0 , 0 0 0 , 0 0 0}$ & $\mathbf{5 , 0 0 0 , 0 0 0}$ \\
\hline Target Bonus (\$) & 100,000 & 100,000 & 0 \\
\hline Incremental Bonus (\$) & $\mathbf{2 \% * ( 1 0 - 5 )}$ & $\mathbf{2 \%} * \mathbf{( 1 0}-\mathbf{1 0})$ & $\mathbf{2 \%} * \mathbf{( 2 - 5 )}$ \\
\hline $\begin{array}{l}\text { Bonus for EVA Improvement } \\
\text { beyond Shareholders Expectations }\end{array}$ & 100,000 & 0 & $-60,000$ \\
\hline Total CEO Bonus & $\mathbf{2 0 0 , 0 0 0}$ & $\mathbf{1 0 0 , 0 0 0}$ & $\mathbf{- 6 0 , 0 0 0}$ \\
\hline
\end{tabular}

Source: Balsley, 2005 (adjusted)

Table 5 presented an example of calculating bonus compensation for the manager in accordance with the methodology of EVA. In the first case, business unit 1, if manager succeeds to create improvement of EVA (in table 5 this was $\$ 10,000,000$ ) above the 
expectation of shareholders (which was $\$ 5,000,000$ ) he will get two parts of total bonus. First, manager will get $\$ 100,000$ of target bonus since he succeeded to increase EVA to the shareholder's expectation. Second, manager will be granted with another $\$ 100,000$ since he improved EVA above expectations (over $\$ 5,000,000$ in this example). According to author Balsley (2005), if the manager realizes an increase above the expectations of shareholders, he wins percentage of incremental increase which is usually about $2-3 \%$ of incremental increase. In this example, the incremental increase is $\$ 5,000,000$ (\$ 10 million total increase minus the expected increase of $\$ 5,000,000$ from shareholders) and $2 \%$ of $\$ 5,000,000$ estimates $\$ 100,000$. Adding these two amounts, manager gets the bonus of $\$ 200,000$. If manager succeeds to increase EVA only to the level of shareholder's expectations (business unit 2 from table 5) he will get only target bonus $(\$ 100,000)$. If EVA is below shareholder's expectations, bonus will not be paid at all (example of business unit 3 ).

Table 6: Hypothetical example of the EVA bonus bank concept

\begin{tabular}{|l|r|r|r|}
\hline \multicolumn{1}{|c|}{ Business Unit 1 } & \multicolumn{1}{c|}{ First year } & \multicolumn{1}{c|}{ Second year } & \multicolumn{1}{c|}{ Third year } \\
\hline Beginning of period EVA (\$) & $20,000,000$ & $40,000,000$ & $10,000,000$ \\
\hline End of period EVA (\$) & $-30,000,000$ & $46,000,000$ & $13,000,000$ \\
\hline Incremental EVA Delivered (\$) & $\mathbf{1 0 , 0 0 0 , 0 0 0}$ & $\mathbf{6 , 0 0 0 , 0 0 0}$ & $\mathbf{3 , 0 0 0 , 0 0 0}$ \\
\hline Expected EVA Improvement (\$) & $\mathbf{5 , 0 0 0 , 0 0 0}$ & $\mathbf{5 , 0 0 0 , 0 0 0}$ & $\mathbf{5 , 0 0 0 , 0 0 0}$ \\
\hline $\begin{array}{l}\text { Achieved Expected EVA } \\
\text { Improvement? }\end{array}$ & yes & yes & no \\
\hline Target Bonus (\$) & $\mathbf{1 0 0 , 0 0 0}$ & $\mathbf{1 0 0 , 0 0 0}$ & $\mathbf{0}$ \\
\hline Incremental Bonus - IB (\$) & $\mathbf{2 \%} * \mathbf{( 1 0}-\mathbf{5})$ & $\mathbf{2 \%} *(\mathbf{6}-\mathbf{5})$ & $\mathbf{2 \%} * \mathbf{( 3 - 5 )}$ \\
\hline $\begin{array}{l}\text { Bonus for EVA Improvement } \\
\text { beyond Shareholders Expectations }\end{array}$ & 100,000 & 20,000 & $-40,000$ \\
\hline Total CEO Bonus & $\mathbf{2 0 0 , 0 0 0}$ & $\mathbf{1 2 0 , 0 0 0}$ & $\mathbf{0}$ \\
\hline Total CEO Year Bonus & $\mathbf{2 0 0 , 0 0 0}$ & $\mathbf{1 8 6 , 6 6 7}$ & $\mathbf{0}$ \\
\hline \multirow{2}{*}{ CEO Bonus Paid } & $\mathbf{1 0 0 , 0 0 0}+\mathbf{1 / 3}$ IB & $\mathbf{1 0 0 , 0 0 0}+\mathbf{1 / 3}$ IB & $\mathbf{1 0 0 , 0 0 0 + 1 / 3 ~ I B}$ \\
\cline { 2 - 4 } & $\mathbf{1 3 3 , 3 3 3}$ & $\mathbf{1 2 8 , 8 8 9}$ & $\mathbf{0}$ \\
\hline Ending Bonus Bank & $\mathbf{6 6 , 6 6 7}$ & $\mathbf{5 7 , 7 7 8}$ & $\mathbf{1 7 , 7 7 8}$ \\
\hline
\end{tabular}

Source: Author's calculation according to the example of author Balsley, 2005.

Since the economic crisis underscored the problems of irrational compensation for managers, the concept of EVA can be used in function of reducing wasteful bonuses. Although EVA bonus is more sophisticated method for creating managers bonus, it is also important to describe EVA bonus bank with one hypothetical example. Specifically, in table 6 it has been shown that the use of formula for bank bonuses by EVA enables deferred payment of bonuses to managers (e.g. for three years). Bonus that is earned in one fiscal year is the sum of the target bonus that the manager receives if it makes EVE increase over shareholders expectations and percentage of incremental bonus (described in table 5). Table 6 presented manager's bonus payment after making $\$ 200,000$ in total, using the formula for the bonus bank. Namely, target bonus is paid in total (in this example target bonus is $\$ 100,000$ ) while the remaining part of the bonus (incremental bonus) is paid up to $1 / 3$ of total amount $(1 / 3$ of $\$ 100,000$ ). In this way, manager gets $\$ 133,333$ ( $\$ 100,000$ of target bonus plus $\$ 33,333$ of incremental bonus) instead of $\$ 200,000$, and the remaining incremental bonus of $\$ 66,667$ is located in the bank bonus for the next period. If business manager in the coming period doesn't achieve EVA increase equally with or above the expectations of shareholders, the bonus will not be paid. The value of the bank bonus will be transferred in the next period, 
which can be a source of motivation for the manager to increase bonus bank amount, and thus the payment of bonuses for the next year. In table 6 it can be seen that bonus bank in first year is $\$ 66,667$. For the second year, manager succeeded the increase of EVA again above the shareholder's expectations, but in smaller amount $(\$ 1,000,000$ above expectations). The total bonus is calculated in the same way, $\$ 100,000$ target bonus plus percentage of incremental bonus (in this case it is $2 \%$ of $\$ 1,000,000$ which estimates $\$ 20,000$ ). Total bonus for second year is $\$ 120,000$, but since bonus bank contained the rest of incremental bonus form first year, $\$ 66,667$, total bonus bank is $\$ 186,667$ ( $\$ 100,000$ of target bonus and $\$ 86,667$ of banked incremental bonus). According to the methodology of EVA bonus bank, payment will be $\$ 128,889$ ( $\$ 100,000$ plus $1 / 3$ of $\$ 86,667$ ). The rest of $\$ 57,778$ is placed in bonus bank for the next year. In third year, manager has not increased EVA up to expectations of shareholders, so bonus was not paid, and the amount of bonus bank was reduced for the percentage of incremental loss $(2 \%$ of $-\$ 2,000,000)$. After reducing bonus bank for $\$ 40,000$ the rest for the next (fourth) year is $\$ 17,778$.

\section{CONCLUSION}

Incentive systems for managers are very complex area of HRM. A mixture of compensations elements, importance of short and long - term incentives for managers and problem of rewarding in the past make this issue more sophisticated. Usually, executive compensations was weakly correlated or even no correlated with the achieved performances. Because of these issues and problems, there is a need for improvement in the design of managerial compensations. Conclusions of this paper are:

- Main elements of CEO compensations are: base salary, annual incentives, long term incentives, all other compensations, change in nonqualified deferred compensation earnings plus change in pension value.

- Basic salary is the smallest part of the total compensations in companies that rewarded its managers with diversified compensation package, and it estimates from $6.97 \%$ to $16.8 \%$.

- Annual incentives are usually double or even several times bigger than salary. These incentives are paid in almost each company where have been created positive business result and performance indicators of ROA, ROE, ROI and EPS.

- Long-term incentives have reached level from $58 \%$ to $74 \%$ of total compensations. The most used are stock options, restricted stocks and performance based equity grants. Related to the long term incentives is also the tendency of rewarding CEO with more deferred compensations.

- Since there are a need of implementing holistic performance measures for defining basis for manager's incentives, authors decided to analyze two measures: BSC and EVA concept.

- One of the best known performance measurement systems is the balanced scorecard that provides an enterprise view of an organization's overall performance. According to BSC, CEO paid bonus percentage should be tied to the percentage of exceeding performance targets, so main part of the CEO bonus will be related to its financial performances, measured by EVA, unit profit and market growth ( $60 \%$ of total earned bonus). The rest of $40 \%$ will be related to customer's indicators $(20 \%)$, indicators of internal processes $(10 \%)$ and indicators of learning and innovation (10\%).

- EVA incentive compensations are based not only on the year increase in EVA, but on the increase that is above expected EVA improvement. Bonus bank is usually used to motivate managers to make decisions that will create superior performances and value for the shareholders continuously. This method will connect results of managers to the deferred bonus payout (payout will be set in defined time period, for example three years). 


\section{REFERENCES}

1. Anđelković, M., and Pešić, D. (2005): Ekonomski dodata vrednost kao osnov za uspostavljanje kompenzacionog sistema za motivisanje menadžera. Poslovna politika, 34(3), p. 54-57.

2. Balsley, H. (2005): Using EVA to Align Management Incentives with Shareholders Interests. Harvard Business School, (http://people.hbs.edu/mdesai/IFM05/HBalsley.pdf)

3. Bititci, U., Garengo, P., Dörfler, V. and Nudurupati, S. (2011): Performance Measurement: Challenges for Tomorrow. International Journal of Management Reviews, doi: 10.1111/j.1468-2370.2011.00318.x.

4. Creamer, G. and Freund, Y. (2010): Learning a board Balanced Scorecard to improve corporate performance. Decision Support Systems, 49(4), p. 365-385.

5. Desai, M. A., Ferri, F. and Treadwell, S. (2006): Understanding Economic Value Added. Harvard Business School Publishing, Case No.: 9-206-016.

6. Dinu, E.M., and Ciora, C. (2012): Best Practices in Incentive Compensation from the Perspective of Value-based Management. Amfiteatru Economic, 14(31), p. 273-285.

7. Evans, J. and Evans, R. (2002): An Examination of Economic Value Added and Executive Compensation. EFMA 2002 London Meetings.

8. Fortune 500. (2011): http://money.cnn.com/magazines/fortune/fortune500/2011/, (Retrieved 15/04/2012).

9. Hay Group. (2011): The Wall Street Journal/Hay Group 2010 CEO Compensation Study.

http://www.haygroup.com/downloads/ww/misc/wsj_2010_ceo_compensation_study_517-11_web.pdf (Retrieved 21/02/2012).

10. Ilić, $\bar{M}$. (2009): Ekonomska dodata vrednost (EVA) u funkciji generisanja vrednosti za akcionare. XIV Internacionalni naučni skup Strategijski menadžment i sistemu podrške strategijskom menadžmentu SM2009. Subotica: Ekonomski fakultet.

11. Ilić, M. (2010): Ekonomska dodata vrednost kao inovativni koncept u merenju uspešnosti poslovanja preduzeća. XV Internacionalni naučni skup Strategijski menadžment i sistemu podrške strategijskom menadžmentu SM2010. Subotica: Ekonomski fakultet.

12. Jensen, M.C. and Murphy, K.J. (2010): CEO incentives - It's not how much you pay, but how. Journal of Applied Corporate Finance, 22(1), p. 64 - 76.

13. Jones, M. (2009): Executive Compensation: A Guide to the Board of Directors. Executive Action Learning Seminars, International Institute of Management. http://www.iim-

edu.org/executiveseminars/executiveseminars_executivecompensationbestpractices.pdf (Retrieved 02/05/2012).

14. Kaplan, R.S. and Norton, D.P. (1992): The Balanced Scorecard - Measures that drive Performance. Harvard Business Review, 70(1), p. 71-79.

15. Kaplan, R.S. and Norton, D.P. (1996): Using the Balanced Scorecard as a strategic management system. Harvard Business Review, 74(1), p. 75-85.

16. Kaplan, R.S. and Norton, D.P. (1996a): The Balanced Scorecard: translating strategy into action. Boston, MA: Harvard Business School Press.

17. Kennerley, M. and Neely, A. (2002): A framework of the factors affecting the evolution of performance measurement systems. International Journal of Operations \& Production Management, 22(11), p. 1222-1245.

18. Kumar, A.V. and Kaura, M.N. (2002): Executive Compensations and Corporate Performance: An EVA Approach. South Asian Journal of Management, 9(3), p. 12-20.

19. Lardenoije, E.J.H., Van Raaij, E.M., and Van Weele, A.J. (2005): Performance 
management models and purchasing: Relevance still lost. Researches in purchasing and supply management, Proceedings of the 14th IPSERA Conference, Archamps, France, p. $687-697$.

20. Lebas, M.J. (1995): Performance measurement and performance management. International Journal of Production Economics, 41(1-3), p. 23-35.

21. Malinić, D. (2007): Kompenzacione šeme za menadžere (Compensation Schemes for Managers). Zbornik radova: Korporativno i javno upravljanju u funkciji razvoja konkurentnosti. Miločerski ekonomski forum. Beograd: Savez ekonomista Srbije.

22. Neely, A.D., Gregory, M. and Plats, K. (1995): Performance measurement system design: A literature review and research agenda. International Journal of Operations \& Production Management, 15(4), p. 80-116.

23. Nudurupati, S.S., Bititci, U.S., Kumar, V. and Chan, F.T.S. (2011): State of the art literature review on performance measurement. Computers and Industrial Engineering, 60(2), p. 279-290.

24. O'Byrne, S.F. (1996): EVA and Market Value. Journal of Applied Corporate Finance, 9 (1), p. 116-125.

25. Ozkan, N. (2011): CEO Compensation and Firm Performance: an Empirical Investigation of UK Panel Data. European Financial Management, 17(2), p. 260-285.

26. Pollanen, R. and Xi, K.K. (2011): The Use of Balanced Scorecard Measures in Executive Incentives and Firm Performance. CAAA Annual Conference 2011.

27. Purcell, N. (2011): Heads I Win, Tail You Loose - The Need to Reform Executive Compensations. Journal of International Business Ethics, 4(1), p. 3-9.

28. Sharma, A.K. and Kumar, S. (2010): Economic Value Added (EVA) - Literate Review and Relevant Issues. International Journal of Economics and Finance, 2(2), p. 200-220.

29. Silk, S. (1998): Automating the Balanced Scorecard. Management Accounting 79(11), p. 38-44.

30. Štangl Šušnjar, G. and Zimanji, V. (2005): Menadžment ljudskih resursa (Human Resource Management). Subotica: Ekonomski fakultet.

31. Stern, J. M., Shiely, J.S. and Ross, I. (2001): The EVA Challenge: Implementing ValueAdded Change in an Organization. New York: John Wiley \& Sons, Inc.

32. Stern, J.M., Stewart, G.B. and Chew, D.H. (1995): The EVA Financial Management System. Journal of Applied Corporate Finance, 8(2), p. 32-46.

33. Wallace, J.S. (1997): Adopting residual income-based compensation plans: Do you get what you pay for? Journal of Accounting and Economics, 24, p. 275-300.

34. Young, S. D. and O'Byrne, S.F. (2001): EVA and Value-Based Management: A Practical Guide to Implementation. New York: McGraw Hill.

35. Zakić, V., Vunjak, N., Bešić, C., and Simić, J. (2012): Significance of Economic Value Added in Shareholder Value Creation Process. Technics Technologies Education Management TTEM, 7(1), p. 180-185. 